\title{
ANNOUNCEMENT
}

\section{NOTICE OF CHANGE IN JOURNAL FORMAT}

At its midyear meeting on April 26, 1986, at Kent State University, the Council of The Paleontological Society voted to change the format of the Journal of Paleontology to a page size of $81 / 2 \times 11$ inches beginning with the January 1988 issue. The purpose of this change is to better serve the members of the Society in their publication efforts. The new format should make possible the publication of more papers each year, thus reducing publication time, and should provide increased opportunities in manuscript design. Although the change may be an inconvenience to some authors currently in the process of preparing manuscripts, the Editors will make every effort to make this transition as painless as possible.

The new page size will allow for the publication of larger figures containing more illustrations. Figures will be published at full page size of $18.3 \times 23.3 \mathrm{~cm}$, or at double column width of $18.3 \mathrm{~cm}$, or at single column width of $9.0 \mathrm{~cm}$. All figures must be mounted on white cardboard and submitted at publication size. Figures must be submitted as glossy prints, and figures containing halftone prints must be submitted as original prints, not as a photograph of the original.

As of this date, all figures in submitted manuscripts must conform to the new format. 